\title{
Queer comrades: towards a postsocialist queer politics Hongwei Bao
}

The radical potential of the term tongzhi comes from its condensation of past and contemporary egalitarian traditions

\section{Citation:}

Bao, Hongwei (2019) 'Queer Comrades: Towards A Postsocialist Queer Politics'. Soundings: A Journal of Politics and Culture 73 (Winter): 24-37.

Perhaps one of the most fascinating changes in the modern Chinese language in the past century has been the use of the term tongzhi (同志). In its early twentieth-century sense of 'comrade', tongzhi was widely used as an honorific in China's revolutionary and socialist eras for people across the political left, although the term's origin from and connection with international communist movements was also evident. ${ }^{i}$ In China's post-revolutionary and postsocialist era, the term has been used by gender and sexual minorities including LGBTQ people for self-identification. Recently it has become a term synonymous with 'queer' in English. From 'comrade' to 'queer', and from a socialist politics blind to human sexuality to a hypersexualised postsocialist queer politics - what has happened and what can we learn from it?

In this article, I trace a brief history of how the term tongzhi has been used in modern Chinese history. In doing so, I identify key moments of political articulation to unravel the socialist politics and revolutionary potentials embedded in each articulation. In particular, I examine how the term has been used in the Chinesespeaking world for queer identification and to mobilise transnational activism. In developing the notion of 'queer comrades' - a creative translation of the term tongzhi as an analytical category, and as part of a critical vocabulary, I aim to conjure up the socialist memories and revolutionary impulses embedded in contemporary queer subject formation and social movements. This article also gestures to the continuing relevance of socialist histories and politics to contemporary queer politics.

\section{Tongzhi as comrade: imagining a new political subjectivity}

Tongzhi as an address term and identity marker is a modern phenomenon. Before the twentieth century, the two characters that make up the term, tong (same) and zhi (ideal or aspiration), both existed in classical Chinese; however, they were separate words often used as a collocation. For example, in Discourses of the States (Guoyu), dating back to the fourth century $\mathrm{BCE}$, we find the following phrase: 'tongxing ze tongde, tongde ze tongxin, tongxin ze tongzhi' ('People with the same last name worship the same totem and have the same nature; hence, they have the same disposition and aspiration'). ${ }^{\text {ii }}$ In History of the Later Han (Hou hanshu), dating back to 445 CE, there is the phrase 'suoyu jiaoyou, biye tongzhi' ('the reason why I make friends with someone is that we have the same aspiration'). ${ }^{\text {iii }}$ Although the combination of the two words tong and zhi was purely random in the aforementioned examples, it was clear that, when put together, the collocation meant 'people with the same ethics and ideals'. The modern use of the term tongzhi as a compound word derives its meanings from this historical context. 
The first recorded instance of the two words being brought together as a compound in modern China was in 1911, when a group of Chinese compatriots launched a political protest to stop the imperial Qing government from handing over China's railway development projects to Western powers. The group called itself Baolu Tongzhi Hui (Railway Protection Alliance). ${ }^{\text {iv }}$ The movement was characterised by nationalism, anti-colonialism and anti-imperialism in a country that had been invaded and partially occupied by foreign powers during and after the two 'Opium Wars' (1839-60) and the first Sino-Japanese War (1894-95). At a time of national crisis, the terms tong and zhi were creatively combined by Chinese nationalists to refer to people sharing the same political ideals. This had profound implications for the subsequent use of the term tongzhi. The new term named and thus helped to bring into being the shared political identity that had begun to emerge in modern Chinese history.

The widespread circulation of the term tongzhi in the modern Chinese language is often attributed to Dr Sun Yat-sen (1866-1925), founding father of the Republic of China. Sun used the term tongzhi in several of his open letters, for example 'Gao haiwai tongzhi shu' ('A Letter to Overseas Compatriots') and 'Zhi nanyang tongzhi shu' ('A letter to Compatriots in Southeast Asia'), both published in 1918. The term functioned as part of a political strategy to garner financial and moral support from overseas Chinese for China's Republican Revolution. Sun's last words before his death in 1925 marked the most widely known use of the term to date: 'geming shangwei chenggong, tongzhi rengxu nuli' ('The revolution is not yet completed; comrades must continue fighting'). In this sentence, Sun referred to all those who shared the same revolutionary ideals as tongzhi. This occurred at a very specific historical moment: the two formerly antagonistic political parties, the Nationalist Party (KMT) and the Communist Party (CCP), had joined hands in 1923 and formed a 'United Front' to fight against their shared enemies, but each party had its own distinct ambitions and interests. Sun's last words served as a call for all political parties to discard partisan differences in order to fight for a shared goal: an independent and united Chinese republic. A nationalist and anti-imperialist stance was clear in this context.

As a term for party membership, tongzhi was initially used by both the KMT and the CCP during the short-lived United Front. But it later lost its popularity within the KMT, after the United Front had collapsed. However, within the CCP, tongzhi persisted as an address term among party members, especially during the Communist Revolution (1921-49) and after the founding of the People's Republic of China in 1949. The CCP Constitution published in 1921 stated: 'those who uphold the CCP's Constitution and policies can be regarded as our Party members and as our comrades (tongzhi) '. ${ }^{\mathrm{v}}$ Despite this official endorsement by the CCP, however, tongzhi went well beyond being an address term for CCP members in its everyday use; rather, it became a term to address all the people who supported communist revolutionary ideals. The term could be used on its own, or in combination with people's first or/and family names, such as Xiaoping tongzhi (Comrade Xiaoping), Wang tongzhi (Comrade Wang), or Lei Feng tongzhi (Comrade Lei Feng). Even today, most people in China still consider tongzhi a positive term to address each other despite its waning popularity in daily use.

The popular use of the term tongzhi produced a political subject, the subject of the Communist Revolution. Its significance lies in the egalitarian political ideals it 
embodies and should also be understood in relation to the terms it replaces. In polar opposition to terms still commonly used in the Republican era (1912-49), such as xiansheng (Sir), daren (Master), xiaojie (Miss) and taitai (Madam), which denote hierarchy and difference in terms of gender and class, tongzhi underlines equality, collectivism and a political subjectivity. Regardless of their family backgrounds and personal experiences, people should be treated the same way if they shared the same politics. The reciprocal use of the term between people signified 'solidarity, equality, respect, and intimacy' and established 'an ideology of egalitarianism' ${ }^{\text {vi }}$ It is important to note that, despite its historical association with nationalism, tongzhi is also marked by a strong sense of internationalism, with the recognition that working-class people all over the world are suffering from the same oppressions and therefore should share the same goals. A tongzhi identity is undoubtedly political. As Jodi Dean points out, 'comrade' names a relation characterised by sameness, equality and solidarity, which for communists is utopian, because it cuts through the determinations of capitalist society. ${ }^{\mathrm{vii}}$

For the first time in modern Chinese history, the 'comrade' identity mobilised the term tongzhi for a political purpose - and to construct a radical subjectivity. It is an identity that is often counterposed to a liberal subjectivity that privileges

individualism and self-interest; tongzhi upholds principles of egalitarianism and social justice. People today often dismiss the Maoist period as a colourless era in which people were deprived of their 'natural' genders, sexualities and desires. But what if we reject a liberal notion of individual subjectivity and private personhood, and instead embrace a political subjectivity imbued with revolutionary passion and collective affect? Insofar as 'queer' represents a disruption of, and departure from, normative gender, sexuality and social norms, the 'comrade' subjectivity is undoubtedly queer.

\section{Queering tongzhi: towards a postcolonial queer politics}

In the post-Mao era, tongzhi as a term of address began to lose its popularity. As China started to embrace neoliberal capitalism in the late 1970s and early 1980s, many people consciously distanced themselves from Maoist and socialist discourses in which the term 'comrade' played a part. As class politics slowly gave way to identity politics, the politicised comrade subjectivity was gradually replaced by desiring subjectivities that celebrated differences in gender, sexuality and identity. Classed and gendered address terms such as xiansheng (Sir), xiaojie (Miss), nüshi (Mrs/Ms) and laoban (boss) resurfaced in everyday language.

Gay identity emerged in postsocialist China at this historical juncture. With the proliferation of medical, legal and academic discourses surrounding homosexuality, a growing number of people began to identify themselves as tongxinglian (homosexuals), a stigmatised term often associated with criminality and pathology. Despite the deletion of 'hooliganism' (liumang zui) from China's criminal Law in 1997, and the removal of homosexuality from the Chinese Classification of Mental Disorders (third edition) (CCMD-3) in 2001, tongxinglian remains a popular term in China's official and media discourses to refer to gay people. In the increasingly rights-conscious queer communities, however, there emerged a refusal to use the stigmatised and pathologised term tongxinglian. A new term for community members' self-identification was needed. Tongzhi filled this gap. 
The 'queering' of the term tongzhi is often attributed to Mai Ke and Edward Lam (also known as Lin Yihua), two gay activists who organised the first Hong Kong Gay and Lesbian Film Festival in 1989. They decided to use tongzhi as the Chinese equivalent of 'gay and lesbian' in the name of the festival. up with a new term for lesbian and gay self-identification was explained in the following way:

In their opinion, 'gay' and 'lesbian' were Western constructs with their specific histories; they failed to capture the essence of Chinese sexual minorities. Tongzhi, however, could create a sense of 'Chineseness' and provide an indigenous identity for Chinese sexual minorities. Both the revolutionists and sexual minorities are marginalised groups living under oppression. They each are united by shared beliefs and striving for a shared cause - for the former, it is the founding of an egalitarian state; and for the latter, it is the promotion of equal rights for sexual minorities. Tongzhi called up the image of communist revolutionaries fighting for their ideals, and by exploiting its revolutionist connotations, it called on sexual minorities to respect themselves and to join the common endeavour of fighting for equality in a heterosexist society. ${ }^{\text {ix }}$

The need to construct an indigenous and transnational Chinese queer identity has been most systematically articulated by Chou Wah-shan, a Hong Kong gay activist and scholar who has proposed a theory of postcolonial Chinese queer politics in several of his books, including Hou zhimin tongzhi (Postcolonial Comrades) (1997); Chou advocates the use of the term tongzhi for queer people in Chinese societies. He describes the strengths of the word as lying in its 'positive cultural references, gender neutrality, desexualisation of the stigma of homosexuality, politics beyond homohetero duality, and use as an indigenous cultural identity for integrating the sexual into the social'. ${ }^{\mathrm{x}}$ In comparison to the stigmatised term gei-lou in Cantonese or tongxinglian in Mandarin, tongzhi indeed seems like a term without negative connotations. All these reasons have led to the popularity of the term among sexual minorities in the Chinese-speaking world.

Chou's tongzhi theory was performative as well as descriptive. It should be seen as an endeavour to politicise tongzhi for a more socially conscious and culturally sensitive politics, and to bring a specific type of radical queer identity and politics to the fore. He enabled the longing for collective empowerment and cultural citizenship that is embedded in the socialist 'comrade' subjectivity to become part of contemporary Chinese queer subjectivity.

In December 1996, the first Tongzhi Conference took place in Hong Kong. About two hundred people from different parts of the Chinese-speaking world attended the event. After the participants had debated heatedly about the possible cultural specificities of queer culture in the Chinese-speaking world, the conference concluded in its manifesto that:

The les-bi-gay movement in many Western societies is largely built upon the notion of individualism, confrontational politics, and the discourse of individual rights. Certain characteristics of confrontational politics, such as 'coming out', mass protests, and parades may not be the best way of achieving 
tongzhi liberation in the family-centred, community-oriented Chinese societies, which stress the importance of social harmony. In formulating the tongzhi movement strategy, we should take the specific socio-economic and cultural environment of each society into consideration. ${ }^{\mathrm{xi}}$

This was the Bandung declaration of Chinese tongzhi. In imagining a transnational community of sexual minorities in the Chinese-speaking world, the manifesto articulates a strong postcolonial and decolonial politics in the context of the globalisation, and often domination, of Western queer politics. The cultural specificities the conference identified, however controversial they may have been, continued to shape Chinese queer identities and cultures in the years to come.

After the socialist term tongzhi had been successfully appropriated for queer use by queer activists in Hong Kong, it soon spread to and subsequently gained popularity in Taiwan and other parts of the Sinophone sphere, and the term was eventually circulated back to mainland China in the mid-1990s, through the internet and transnational queer activism. By the end of the 1990s, a fast-developing internet culture had made the term popular among queer people across the Chinese-speaking world, with popular terms such as tongzhi websites, tongzhi literature, tongzhi films, tongzhi bars, tongzhi venues and tongzhi culture. The 'subculture of homosexuality' (tongxinglian ya wenhua) has now gradually become a tongzhi 'culture' (wenhua). The queer use of the term tongzhi has thus travelled from the 'margins' of the Sinophone sphere to mainland China, challenging PRC hegemony in transnational cultural production.

It is important to note that transnational queer cultures in the Chinese-speaking world have played an important role in the development of queer activism in mainland China. Lesbian and gay representatives from mainland China attended the Chinese Tongzhi Conferences held in Hong Kong in 1996, 1998 and 1999, and in Taiwan in 2001. In summer 1998, the first National Men and Women Tongzhi Conference was held in Beijing, attended by thirty lesbians and gays from different provinces in China, together with representatives from the Sinophone sphere. In the autumn of 1998, the first National Women Tongzhi Conference was held in Beijing, and twenty participants from different parts of China attended the conference. These national and international conferences have solidified the queer use of the term tongzhi in the PRC and crafted a strong sense of transnational solidarity based on a linguistic and cultural affinity of 'Chineseness'.

\section{Tongzhi Acting Up}

In December 2000, Hunan Satellite Television hosted a talk show programme called Approaching Homosexuality (zoujin tongxinglian). Three guest speakers were invited to the discussion panel: Li Yinhe, a sociologist researching on homosexuality; Cui Zi'en, a writer and filmmaker; and Shitou, a lesbian artist. This was the first time that a self-identified gay man and a lesbian 'came out' in PRC's official media. In the programme, the TV host, studio audience and the expert panel primarily used the word 'tongxinglian' to refer to lesbians and gay men. Shitou, by contrast, insisted on identifying herself as tongzhi. When a member of the audience asked about the connotation of term, Cui Zi'en traced the queer use of the term tongzhi to Edward Lam and explained the meaning of the term as 'sharing the same aspirations and dispositions' (zhitong daohe). Cui also emphasised that terms such as tongzhi and 
tongxinglian should both be used with pride and dignity. The event marked the first time that queer activists in the PRC consciously refused the stigmatised tongxinglian discourse imposed by mainstream media and 'queered' tongzhi for positive selfidentification.

In 2001, a few heterosexual-identified students from Peking University's Film and Television Society, including Zhang Jiangnan and Yang Yang, decided to organise a queer film festival, for humanitarian reasons and out of their love for art. They invited Cui Zi'en to be the curator. Programming was easy, but naming the festival became a problem, as all student-organised activities had to be approved in advance by the university's Youth League - the youth branch of the Communist Party. Knowing that the term tongxinglian would not be approved because of the political sensitivity of queer issues in China, the students tried their luck by branding the event as 'the first Chinese Tongzhi Cultural Festival'. Unaware of the queer association of the term, the Youth League approved the proposal. The event lasted a few days and attracted enormous media attention. As Chinese and international journalists enthusiastically reported on 'China's first gay and lesbian film festival', the university authority realised what had happened and decided to shut down the festival before its official closing event took place. This event marked the start of the queer use of the term tongzhi for activist purposes in and outside China's queer communities, and the spread of the term was facilitated by China's fast developing queer identities, communities and activism from the beginning of the twenty-first century onwards.

Queer activism has developed rapidly in the past two decades. This reflects the rapid development of queer communities in urban China, enabled by a relatively tolerant political environment and social atmosphere, and rising consciousness of queer identities and citizen rights, as well as continuing community building and activist efforts. Tongzhi, as a term denoting sexual identity, community and rights, has been firmly established in contemporary China's public discourse since the 2000s. There has been a proliferation of tongzhi organisations (zuzhi), movements (yundong) and spaces (kongjian). Meanwhile, in China's queer communities, debates about what constitutes tongzhi politics, and furthermore Chinese tongzhi politics, has never stopped. Thus, for example, in the Sailor Moon debate (aka the Pretty Fighter debate), tongzhi was described as a Chinese version of gay identity politics. Although this view was not shared by all community members, a separation between gay identity politics and queer politics began to take shape in the contemporary PRC in the early 2010s. The Sailor Moon debate also witnessed the rise of the term $\mathrm{ku}$ 'er, a transliteration of the English term 'queer', to articulate a feminist-led queer politics in the PRC context.

Since 2012, a new generation of queer youth has become increasingly vocal about queer and women's rights, despite China's tightening political control under the current government. Born in the 1980s and 1990s to China's 'one-child generation', these young people seem to fear little. Contrary to the more cautious way of queer organising in the past, these young people were quick to follow Western queer and feminist practices, seemingly unbothered by the questions of 'Westernness' versus 'Chineseness' that constantly haunt the older generation of feminist and queer activists. They are represented by the feminist activism carried out by the 'Feminist Five' and Changsha Tongzhi Pride, led by Xiang Xiaohan. 
On 17 May 2013, a public parade was held in Changsha to celebrate the International Day against Homophobia, Transphobia and Biphobia (IDAHOBIT). More than a hundred queer people from different parts of China gathered in a scenic riverside area of Changsha's university district. They walked together with rainbow flags and a banner that proclaimed, 'tongzhi are ordinary people' ('tongzhi yi fanren'). They also shouted slogans such as 'I am tongzhi and I am proud', 'mainland tongzhi conquer 2013', 'no more fear, we are the world!', and 'support tongzhi, fight discrimination' xii The day went on smoothly and ended with a queer activist experience-sharing event in a café in the evening. Four activists were later taken away by the police for questioning, all but one being released after a few hours. The nineteen-year-old organiser of the event, Xiang Xiaohan, who was the director of a local queer nongovernmental organisation, was detained for twelve days. After his release he commented: 'Next time they might detain me for fifteen days. If that's what it takes to hold another event, then that's fine by me'. xiii

The Changsha Pride parade, together with other IDAHOBIT events held in different parts of the country on the same day, marked an important moment in China's queer activism. ${ }^{\text {xiv }}$ It showed the political potential that tongzhi activism engenders, but also the potential for success - however brief and precarious - of a post-Stonewall type of identity politics, characterised by visibility, coming-out and pride. The event featured both traditions: the socialist slogans, tactics and ethos from the past have been borrowed and appropriated by the young generation of filmmakers - consciously or unconsciously. While this parade bore a striking resemblance to pride parades in the West, its form of mass mobilisation and its use of the legitimate and yet ambiguous term tongzhi is deeply rooted in China's historical experience and collective memory.

Lisa Rofel describes queer activists in China as 'nomadic subjects' because of their flexible use of spaces and ad hoc organising strategies: 'They do not remain in a fixed relationship to power; they manoeuvre within and around the various powers that shape subjectivities, socialities, political beliefs and economic inequality in China'. ${ }^{\mathrm{xv}}$ Elisabeth Engebretsen identifies 'a strategic queer politics of contingency':

On one level, this political strategy appropriates tacit articulations of Pride politics and rights discourses. However, it also focuses on communication and outreach to the general public, allies as well as queers, instead of giving primacy to overt political confrontation directed at the government. ${ }^{\mathrm{xi}}$

Indeed, queer activists in China have been actively negotiating a transnational queer activist politics of visibility and pride with acute attention to local conditions and contexts. They have strategically made use of time, space and 'grey areas' in public policy to create a queer activist space. Despite the tightening of state control in recent years, it is this unrelenting nomadic activism and strategic effort to find local allies that should give us hope.

In recent years, queer commercial venues have mushroomed in urban areas, as a pink economy is rapidly developing in Chinese cities. Shanghai Pride, with its emphasis on entertainment and consumerism, has been held annually since 2009 without much government intervention. PFLAG (Parents and Friends of Lesbians and Gays) China, the biggest LGBTQ organisation in the PRC, has organised nationwide meetings, festivals, cruise ship tours and even expensive group same-sex wedding ceremonies. 
Launched in 2012, Blued has become the largest gay social network app in China and in the world - and was valued at $\$ 600$ million in 2016. xvii An increasing number of queer people are enjoying the freedom that has been brought about by consumerism and a middle-class lifestyle. It seems that in today's China, people can do almost anything in their own private homes and in commercial venues, as long as they accept the status quo and do not demand political rights. Queer identity is allowed to exist as a private, individual-based, consumption-driven and apolitical identity. But any public mobilisation in the name of rights and social justice is immediately seen as problematic

As collective organising gives way to individual consumerism and hedonistic pleasure, it is perhaps time to reinvigorate tongzhi as a radical queer identity. In its century-long history, the term tongzhi has been used to signify a political subjectivity, an expression of solidarity among marginalised social groups, and a continuity with a revolutionary past. It is now time to think about the radical political potential of the term by drawing on its historical moments of political articulation. This is not a call to arms for an uncritical adoption of a Stonewall type of confrontational politics, but a call for anti-hegemonic collective action, and a call to keep experimenting with innovative global and nomadic activist strategies to fight against the hegemony of both the state and neoliberal capitalism. After all, to quote Sun Yat-sen again, 'the revolution is not yet completed; comrades (tongzhi) must continue fighting!'

\section{Tongzhi as 'queer comrades'}

As this brief history of tongzhi demonstrates, tongzhi is not only a linguistic term; it is a newly articulated sexual identity that has underpinned much of the past thirty years of queer subject formation and activism in the PRC and beyond; and it is often imagined as a politicised sexual subjectivity. Perhaps one of the most remarkable things about queer life in China is the emergence of tongzhi identity and activism - an increasingly politicised mode of queer subjectivity and politics. In an era of neoliberalism both in China and in much of the rest of the world, the depoliticisation of politics has become the norm; this politicisation of sexual identity thus has significant implications and holds out positive promises for a radical and progressive left politics.

'Tongzhi', or 'queer comrades' (a creative English translation that captures its semantic pun, tongzhi as both 'comrade' and 'queer'), is a term that has significant political potential. Its dual meaning provides the underpinning of my argument in this article: I regard as problematic the privileging of one meaning ('queer') over the other ('comrade') in the popular use of tongzhi in China's queer communities. And I attribute any such privileging to contemporary China's postsocialist condition, which is characterised by the continuing existence but gradual erasure of China's socialist past and the state's active incorporation of neoliberal capitalism. If China's postsocialism is characterised by the co-existence of modes of economic, political and ideological legitimacy, and cultural production, that correspond to different periods of its history, the term 'queer comrades' can be seen as an articulation of forms of subjectivity, power, governmentality and social imaginaries that have been produced in this shift. 'Queer comrades' is embedded in the context of post-cold-war neoliberal capitalism. This concept disrupts transnational neoliberalism by conjuring up spectres from the socialist past, but also opens up alternative social imaginaries. 
I suggest that, among other things, an important lesson we can learn from tongzhi identity and activism is the recognition of socialist aspiration and longing in constructing queer identity and activism, together with the power and political potentials that this brings about. Indeed, in a global neoliberal era marked by the erosion of political identities in the face of individualism and consumerist drives, it is more important than ever that socialist histories and legacies are recognised, together with socialist experiences of anti-authoritarian and anti-capitalist struggles, and aspirations and longings for an egalitarian and just society. I argue that by drawing strategically on identity formation and experiences of grassroots mobilisation from China's socialist past, in conjunction with aspirations and longings for a more egalitarian and just society, queer people in China today have begun to construct a radical and democratic response to the actions of a repressive state and the neoliberal capitalist vision it now promotes. Tongzhi, as an identity category and as a form of activism, offers valuable insights into how social movements and radical politics can develop today in the context of global neoliberalism. Queer activism in China could thus go beyond the concerns of sexual minorities in China and become a site of critical enquiry for people involved in radical politics and social movements in a transnational context.

In conclusion, I propose the notion of 'queer comrades' as an analytic lens through which to examine subject, power, governmentality, social movements and everyday life in China. Such an expansive approach suggests that subjects in China today are not only constructed by multiple discourses; they also live in shifting temporalities, all of which are critical for both socialism and neoliberal capitalism. While many researchers have correctly identified the role of neoliberal capitalism in constructing desiring subjects in contemporary China, they have often neglected or undermined the impact of China's socialist past on today's subject formation and politics. Queer identities and activism in contemporary China demonstrate that the socialist 'comrade' has become a foundation of, and even a catalyst for, the postsocialist gay subject. The discussion of 'queer comrades' therefore offers a more complex and nuanced understanding of identity, power and politics in contemporary China. It also opens up possibilities for alternative forms of subjectivity and politics that are not constrained by nation states and neoliberal capitalism.

This article is a revised excerpt from the Introduction and Chapter 3 of my book Queer Comrades: Gay Identity and Tongzhi Activism in Postsocialist China, NIAS Press, Copenhagen 2018. I wish to thank NIAS Press for giving permission to reprint some materials from the book and the editors of Soundings for encouraging me to develop my argument in this article.

Hongwei Bao is an assistant professor of media studies at the University of Nottingham. He is the author of Queer Comrades: Gay Identity and Tongzhi Activism in Postsocialist China, NIAS Press, Copenhagen 2018. 
${ }^{\mathrm{i}}$ This article primarily focuses on the use of the term tongzhi in the PRC (People's Republic of China) context. For discussions of the term in the Sinophone context, see Howard Chiang and Ari Larissa Heinrich, Queer Sinophone Cultures, Routledge, London 2013.

ii Liu Yonghou and Chen Xiaomin, 'The semantic change of tongzhi and shifu', International Journal of Language and Linguistics, 2, 4, 2015, p74.

iii Ibid, p74.

iv Chen Yuzhi, 'Tongzhi in China: A social marker or not?', Working Papers in Educational Linguistics 27, 2, 2012, p10.

${ }^{\mathrm{V}}$ Ibid, p10.

${ }^{\text {vi }}$ Andrew D. Wong, 'The trouble with tongzhi: The politics of labelling among gay and lesbian Hong Kongers', Pragmatics, 18, 2, 2008, p278.

vii Jodi Dean, 'Four Theses on the Comrade', E-Flux, 86, 2017: www.e-

flux.com/journal/86/160585/four-theses-on-the-comrade/.

viii Chou Wah-shan, Houzhimin tongzhi (Postcolonial tongzhi), Xianggang tongzhi chubanshe, Hong Kong 1997, p360.

ix 'The semantic change of tongzhi and shifu', p76.

${ }^{x}$ Chou Wah-shan, Tongzhi: Politics of Same-Sex Eroticism in Chinese Societies, Haworth Press, New York 2000, p2.

xi '1996 Chinese Tongzhi Conference Manifesto': www.utopia-asia.com/tongzhi.htm.

xii See my Queer Comrades: Gay Identity and Tongzhi Activism in Postsocialist

China, NIAS Press, Copenhagen 2018.

xiii Xiang Xiaohan, 'Changsha LGBT Pride takes place, organiser detained': https://www.youtube.com/watch?v=N4aS9Sd1Z04.

${ }^{\text {xiv }}$ Elisabeth L. Engebretsen, 'Of pride and visibility: The contingent politics of queer grassroots activism in China', in Elisabeth L. Engebresten and William F. Schroeder (eds), Queer/Tongzhi China, NIAS Press, Copenhagen 2015, p95.

${ }^{\mathrm{xv}}$ Lisa Rofel, 'Grassroots activism: Non-normative sexual politics in postsocialist China', in Wanning Sun and Yingjie Guo (eds), Unequal China: The Political Economy and Cultural Politics of Inequality, Routledge, London 2013, p158.

xvi 'Of pride and visibility', p95.

xvii Javier C. Hernández, 'Building a community, and an empire, with a gay dating app in China', New York Times, 16 December 2016. 